UDC 338:339

\title{
National innovation system of India: genesis and key performance indicators
}

\author{
Ivan N. Bokachev \\ PAO "Vympel-Kommunikatsii" \\ 108 Marta St., bldg. 14, Moscow, 127083, Russian Federation
}

\begin{abstract}
The article discusses the formation of the India's national innovation system (NIS), which passes through the phases of protectionism, liberalism and duality. Special attention is paid to the peculiarities of the India's innovation system based on efficiency indicators, such as gross domestic expenditures on research and development, exports of high-tech products, as well as foreign direct investment in high technology sector. The paper notes that India is one of the most attractive countries for investing in the innovation sector. The author also highlights the negative aspects of NIS development in India, such as imbalances in income and wages, low literacy and high levels of poverty, uneven inflow of foreign investment in different regions, lack of innovation culture in manufactured products, etc. The article especially notes that India after the start of the process of economic liberalization has grown economically in terms of GDP, exports, employment, investment, the inflow of foreign technology and investment, the ICT industry, and the internationalization of investment in research and development sphere.
\end{abstract}

Keywords: national innovation system, India, economic development, R \& D, innovation, high technologies, innovation potential

\section{Introduction}

As of today one of the key factors of economic growth is innovation and new technology using. India is trying to use science and innovation to improve the economic fields effectiveness and solve most of the social-economic problems. The Indian national innovation system began to form slowly step-by-step. The specification of system becoming features and its characteristics with different figures of effectiveness has special relevance in the national innovation system research to deep and concretize the theory of national innovation system (NIS).

Due to India's liberalization process at the beginning of 1990s there is a special interest to the facts occurred in Indian economy, especially by the end of 1990s. Special attention is paid to the Indian innovation system evolution and effect of liberalization policy to the different economic issues, such as economic growth rate, FDI flow, R\&D investments from the foreign companies and etc. The expectations are too high in India and in the other countries, where India may

(C) Bokachev I.N., 2019

(c) This work is licensed under a Creative Commons Attribution 4.0 International License https://creativecommons.org/licenses/by/4.0/ 
become a country with strong economy. As of today India's growth is in the center of global economy interest.

Indian researches reckons that India is ready to make a shift from developping to developed country. They suppose, that this level can be reached if economic growth rate more than $8 \%$ is remain till 2021 .

\section{Literature review}

The article is written on the basis of official materials from the World Bank, Department of Science and Technology of India, Aalborg University, and the media. The author used official statistics from the Department of Science and Technology of India, the Department of Industrial policy and promotion, as well as official annual reports and government documents such as Towards a Decade of Innovation 2010-2020 made by the National Innovation Council in India, Research and Development Statistics at a Glance 2017-2018 composed by Department of Science and Technology.

The work also used the publications of foreign scientists and experts in the field of development of national innovation systems, R \& D, innovation and new technologies, including the standpoint of the state influence. Thus, the works of R. Mascarenhas (Mascarenhas, 1982) and C. Cooper (Cooper, 1988) are devoted to the achievement by the Indian government at the first stage of the NIS formation (1950-1980s) of goals to protect the local innovation market. Cooper addressed supply and demand factors in technology imports and technology absorption in Indian industry.

N. Kumar, A. Agarwal (Kumar, Agarwal, 2000) addressed issues such as liberalization, outward orientation and in-house $\mathrm{R} \& \mathrm{D}$ activity of multinational and local firms to understand the trends of the second phase of the India's NIS genesis. The study also used the works of such foreign scientists as S. Getty (Getty, 2003), K. Khandelwal (Khandelwal, 1981), R. Bhojani (Bhojani, 1985) and others whose publications were used in this article.

\section{Methodology}

There were methods of description, analysis and synthesis used during the research. The paper emphasizes on the research of the India's national innovation system genesis process. The author divided the hole genesis process into three phases with the following identification of the NIS special aspects at each stage of the system formation. The special practical significance of the study is relating to the analysis of key performance indicators of the India's NIS based on official data from Indian departments and agencies and other international databases. The author used data from the World Bank, the Department of Science and Technology of India, annual reports of research organizations in India in order to create a comprehensive system of performance indicators to establish the degree of Indian NIS development at the present stage. Such data allow us to search for business opportunities in the field of science, new technologies and innovations in India, as well as to consider Indian NIS as a catalyst for the country's economic growth in the face of rapidly growing demand for innovative and high-technology goods in the world. 


\section{The phases of the Indian innovation system development}

Indian national innovation system have three crucial phases of its genesis (Figure 1): protection (1950-1980s); liberalism (1980-2000s); and duality (2000 present).

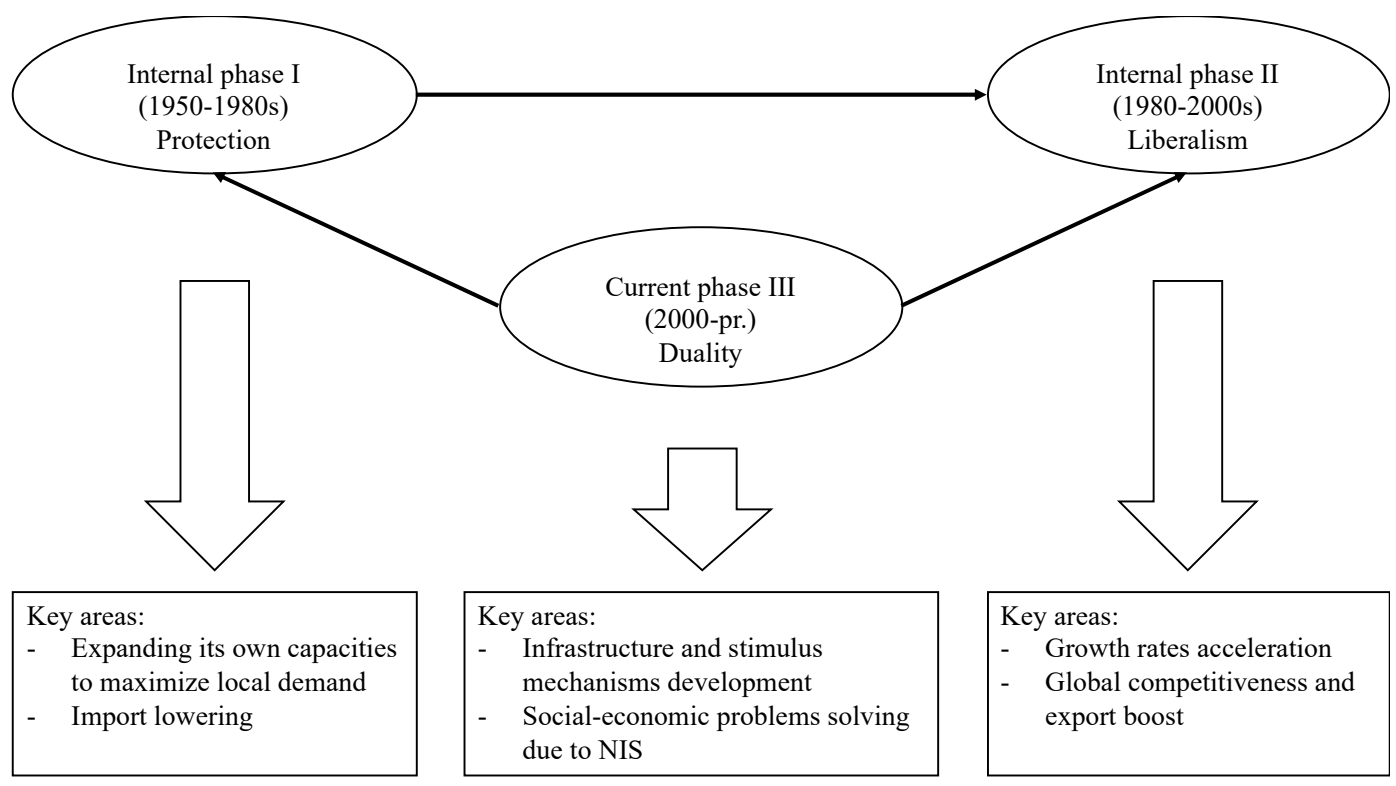

Figure 1. Phases of the India's national innovation system genesis

Source: composed by the author on the basis of: Development, Innovation and International Political Economy Research, 2018. Denmark: Aalborg University, 2018.

Phase I (1950-1980s). Indian national innovation system in 1950-1980s years had been developing by to main factors: believe in science and new technologies; local protection policy. The main government concern was creating protective conditions for the local producers form foreign companies. Jawaharlal Nehru, the premier in past, said, that India cannot be economical or political independent, if the country doesn't strengthen its scientific and technological potential (Eisemon, 1984).

The government leaders warried about dominance and incidence of foreign companies, if it is free market entry. So India tried to create the local innovation potential to meet the internal demand and to decline the import dependence. The Indian government didn't emphasize on industry development to improve the country's competitiveness in the world. That fundamental factor shaped the national innovation system on the first phase.

In order to reach the government goals in the first phase India had made series of actions, such as industrial policy that clearly define the roles of the private and public sectors, the regulation of private investment through industrial licensing, and the control of technology imports to encourage domestic R \& D. It led to the scientific research opportunities development on the local level (Cooper, 1988).

There were two main events in production sector during the first phase. From one hand, India reached higher degree in local technology opportunities, but 
from the other hand, Indian companies still didn't make any large innovations for its products to create effective export market.

Indian companies produced cheap products to meet local demand and several companies began to create its own R \& D due to imported technologies adaptation. By the beginning of the 1970s most of the R \& D institutes in India were mainly trying to catch up with research and development level in developed countries. Although they provided scientific knowledge and created a solid research base, often they did not directly contribute to socio-economic problem solving (Mascarenhas, 1982). The government attempt to force Indian companies to buy local technologies in R \& D organizations had been stopped in 1975 and by the 1980s India began to liberalize its new technology import policy.

In 1974 Indian government accepted a 5-year scientific and technical development plan worked upon the National Scientific and Technical Committee. This plan had to facilitate the incorporation and adoption of new technologies and develop its own production capacities. In fact, it was a government R \& D program, which combined the forces of more than 2 thousand scientists in new technology field in many production sectors.

Phase II (1980-2000s). By the middle of 1980s the Indian government came to a conclusion that the country need strong national innovation system to reach the high level of competitiveness and improve the economy situation. This issue was clear when production policy liberalization has been appointed in 1991 year. It led to the crucial changes in such spheres like industry licensing, foreign investments, international technology agreements, the public sector and monopolies and the Law on Restrictive Trade Practices. It meant that India changes its directions from import control to export promotion.

The liberalization process influenced the effectiveness of the Indian NIS. The import of foreign technologies, production operations and investments had increased from 1990s (Goldar, Ranganathan, 1998). One of the main result was the opening of R \& D centers in TNCs in India and fence-mending with Indian $S \& T$ institutions. Another highlight is the operation outsourcing of many foreign companies to India, mainly in the service sector. It helps foreign companies to reduce costs and increase their efficiency due to the highly skilled workforce available in India (Getty, 2003). The structure and size of outsourcing is growing in India. This is an important issue at the time of "knowledge economy", because skills are just as valuable as technologies and products.

If we are talking about export and competitiveness, the progress in many production sectors was slow. Nevertheless, Indian IT sector, which appeared in 1980-1990s as the main sector, led to the extremely high export performance, especially in digital solutions field. There is a common thing that the availability of skilled manpower is the main reason for this. There were proceeded a range of significant measures to promote and expand the IT industry in the beginning of 1980s. In 1984 year there was an IT policy which lifted output restrictions in computer sphere, liberalized a licensing system and import duties to provide the economy of scale and increase competitiveness.

The 1985 Electronics Policy states that "software is growing in electronics, and India can be the best at this field" (Bhojani, 1985). The computer industry was 
largely introduced in the private sector, and hundreds of firms appeared in India soon due to the competitive environment. Subsequently, India became a leading player in the software market in the 1990s. India's success in this sector was largely driven by intensive R \& D efforts by companies and the availability of strong basic research capabilities in the country. The 1990s liberalization in the 1990s demonstrated the potential of the Indian innovation system to achieve higher growth rates, despite the persistent weaknesses of the Indian innovation system, such as continuing problems in establishing closer ties between research institutions and companies.

The 1990s are the years in severe conditions of a budget deficit, high inflation, and an unstable balance of payments for India. The country's economy was on the verge of collapse. The IMF, in exchange for help, demanded economic liberalization.

The reforms had a major impact on the innovation sphere development. The industrial licensing was canceled (it was retained in a reduced form in several sectors), foreign investments of up to $51 \%$ of the authorized capital were automatically approved, inefficient state enterprises were reorganized or privatized. Nevertheless, significant changes in the innovation sphere began to occur only a decade later, and in the 1990 s the state continued to finance up to $70 \%$ of scientific research, R \& D costs were below $1 \%$, and foreign investment grew slowly.

An important factor in the NIS development was the reform of intellectual property law. The Indian Law on Patents in 1970 underwent significant changes in 1990, 2002, 2005 and now meets the requirements of international law.

Phase III (2000s - present). India came with a dualistic hangover by the beginning of the $21^{\text {st }}$ century. On the one hand economy liberalization and 1991 reform, the active capital raising, business and educational ties with the USA, gaining world first places in the IT industry development, young people who speak English and have more and more open access to education and work, a strong private sector, developing legislative and financial system and an average GDP growth of $9 \%$ per year. On the other hand, an extremely low living standards of the vast majority of the population ( $80 \%$ of the Indian population live on 2 dollars a day), infrastructure problems of access to water, food, medicine, ethnic problems, bureaucracy and actively developing neighbors - China, Korea and Pakistan, in relations with which the technological lag is far from favorable for India.

Under these conditions, the development of science and technology for India is vital, since it will contribute to the solution of many problems in internal development and will allow the country to become a world leader. The Indian economy is growing at a rate of 6-8\% per year, and exports are growing at 30\% (CAGR). So innovation becomes the main success factor.

Main attention to the $\mathrm{S} \& \mathrm{~T}$ sector development is given in the five-year plans, which have been developed by the planning commission of India since 1947. These plans provide results assessment of the previous five-year period and propose initiatives for the next five years. The five-year plan (2007-2012) proposes a large-scale strategy for the $\mathrm{S} \& \mathrm{~T}$ development. It is envisaged to increase the number of scientists, stimulate the development of basic sciences, promote industry and science connections, develop the educational system of India and increase its openness and accessibility for all segments of the population. The cur- 
rent five-year plan identifies priority areas of $\mathrm{S} \& \mathrm{~T}$ development: the aerospace industry, pharmaceuticals, IT, biology, nuclear energy and ocean research.

Among the stated goals we can see an increase in $\mathrm{R} \& \mathrm{D}$ expenditures from 0.9 to $2 \%$ of GDP, and education expenditures from 4 to $8 \%$ of GDP (Webeconomy.ru, 2017).

The current decade (2010-2020s) has been declared the "Decade of Innovation" in India and the National Innovation Council (NIC) has been created to draw up a "roadmap" for the decade as an urgent step. The National Innovation Council is expected to create sustainable and cost-effective solutions for people at the bottom of the pyramid. 1 billion US dollars is intended to promote new ideas for the inclusive development of innovation in the country (National Innovation Council, 2018). One of these ideas includes the development of innovative mechanisms within microcredit systems. India has already managed to show the effectiveness of such mechanisms when local banks issued microloans to poor peasants under the guarantee of the entire community, as a result of which the peasants received financial assistance, and default on debts was minor. In the current situation, it is necessary to develop such mechanisms from an innovative point of view in order to increase their effectiveness and accessibility.

\section{Key performance indicators of the India's national innovation system}

Assessing the work of the India's national innovation system, it is necessary to take into account many indicators, including performance indicators of its elements. So, one of the main performance indicators is the gross expenditure on R \& D (GERD), including \% of GDP.

As can be seen from the Table 1 national expenditures on R \& D tripled from 5 billion dollars in 2004-2005 up to 15 billion dollars in 2016-2017. R \& D expenditures as a percentage of GDP in 2016-2017 amounted to 0,75. The Government of India plans to increase R \& D costs to 2\% of GDP. India's share of world $\mathrm{R} \& \mathrm{D}$ spending is 2,7\% in 2016-2017 (Government of India, 2017).

Table 1

National expenditure on R \& D by sector in India, million dollars, \% of GDP, 2004-2017

\begin{tabular}{lccccc}
\hline \multicolumn{1}{c}{ Sector } & $\mathbf{2 0 0 4 - 2 0 0 5}$ & $\mathbf{2 0 1 3 - 2 0 1 4}$ & $\mathbf{2 0 1 4 - 2 0 1 5}$ & $\mathbf{2 0 1 5 - 2 0 1 6}$ & $\mathbf{2 0 1 6 - 2 0 1 7}$ \\
\hline Central Sector & 3331,07 & 6644,21 & 7069,42 & 7179,85 & 7320,24 \\
State Sector & 428,87 & 1017,00 & 1037,95 & 1089,10 & 1147,20 \\
Private Sector & 1333,97 & 5214,70 & 5337,70 & 5901,17 & 6549,38 \\
Higher Education Sector & 233,44 & 685,28 & 552,09 & 571,47 & 593,83 \\
Total & $\mathbf{5 3 2 7 , 3 6}$ & $\mathbf{1 3 5 6 1 , 1 8}$ & $\mathbf{1 3 9 9 7 , 1 6}$ & $\mathbf{1 4 7 4 1 , 5 8}$ & $\mathbf{1 5 6 1 0 , 6 5}$ \\
\% of GDP & $\mathbf{0 , 7 4}$ & $\mathbf{0 , 7 1}$ & $\mathbf{0 , 6 9}$ & $\mathbf{0 , 7 2}$ & $\mathbf{0 , 7 5}$ \\
\hline
\end{tabular}

Source: Official statistics of R \& D data 2017-2018 / Department of Science and Technology of India. 2017. http://dst.gov.in/research-and-development-statistics-2017-18-december-2017 (accessed: 01.02.2018)

In a country with an East Asian model of economic development, the state is the main R \& D investor. The distribution of costs for research in 2016-2017 looked like this: $54,24 \%$ of the expenditures were spent by the government, of which 
$8 \%$ was spent by state sector, $41,9 \%$ by private sector, and $3,86 \%$ by educational sector.

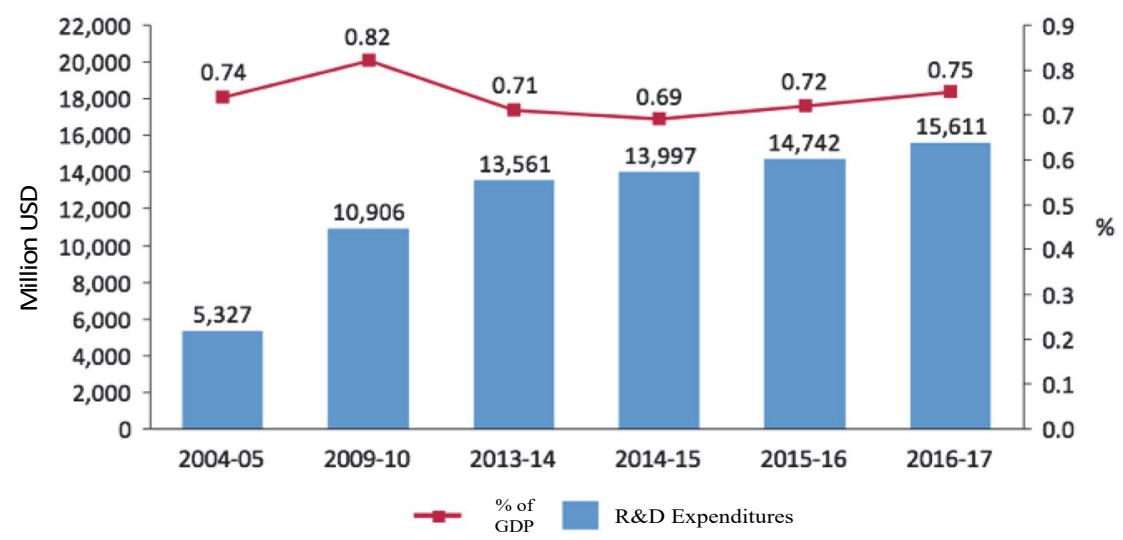

Figure 2. Dynamics of R \& D expenditures, million dollars, \% of GDP, 2004-2017

Source: composed by the author on the basis of: Official statistics of R \& D data 2017-2018 // Department of Science and Technology of India. 2017. http://dst.gov.in/research-and-development-statistics2017-18-december-2017 (accessed: 01.02.2018).

It should be noted the investment growth by the private sector. Investments of private enterprises in research and development have increased 7 times since 2004. Such a rapid growth of investments was probably associated with the publication in 2003 of an official government document "Science and Technology Policy" where the private business sector plays a special role in the innovations and high technologies development.

Higher education institutions still account for the smallest share of R \& D expenditures, but nevertheless, in absolute terms, their growth is noticeable: since 2004, investment in research has increased almost 4 times.

In comparison with developed countries, which restored their R \& D indicators in the post-crisis period rather quickly, for India this process took much longer, therefore, the positive dynamics of $\mathrm{R} \& \mathrm{D}$ expenses growth is observed only from 2014-2015 (Figure 2).

In addition to the national budget for $\mathrm{R} \& \mathrm{D}$, there is also funding that is provided by government research departments or agencies for research organizations and universities. The Table 2 presents data on R \& D financing by the largest government agencies and departments of India in the field of science, technology and innovation.

As we can see from the Table 2, the largest R \& D investment comes from Defense Research \& Development Organisation (DRDO). It accounts for almost $40 \%$ of total expenditures among the organizations. In second place for R \& D funding is the Department of Space (DOS), which in 2014-2015 invested US 954 million dollars in research. Oddly enough, but the Department of Science and Technology, as part of extrabudgetary funding, provides very little support for R \& D, which as of 2014-2015 amounted to 443 million dollars (7,71\%). Moreover, it is worth noting that the DST R \& D expenses began to decrease markedly, starting from 2012. 
Expenditure on R \& D by the major scientific organizations in India, million dollars, 2005-2015

\begin{tabular}{|c|c|c|c|c|c|c|}
\hline Organization & 2009-2010 & 2010-2011 & 2011-2012 & 2012-2013 & 2013-2014 & 2014-2015 \\
\hline $\begin{array}{l}\text { Council of Scientific \& } \\
\text { Industrial Research (CSIR) }\end{array}$ & 548,23 & 639,24 & 666,64 & 542,78 & 529,54 & 547,06 \\
\hline $\begin{array}{l}\text { Defence Research \& Develop- } \\
\text { ment Organisation (DRDO) }\end{array}$ & 1742,58 & 2214,68 & 2103,24 & 1845,63 & 1857,39 & 2174,88 \\
\hline $\begin{array}{l}\text { Department of } \\
\text { Atomic Energy (DAE) }\end{array}$ & 793,27 & 623,02 & 696,20 & 595,11 & 652,50 & 668,50 \\
\hline $\begin{array}{l}\text { Department of } \\
\text { Biotechnology (DBT) }\end{array}$ & 149,55 & 200,90 & 206,44 & 192,24 & 177,22 & 167,42 \\
\hline $\begin{array}{l}\text { Department of Science } \\
\& \text { Technology (DST) }\end{array}$ & 408,33 & 465,40 & 501,63 & 443,49 & 421,43 & 443,06 \\
\hline Department of Space (DOS) & 855,93 & 978,10 & 805,85 & 905,82 & 883,33 & 954,46 \\
\hline $\begin{array}{l}\text { Indian Council of Agricultural } \\
\text { Research (ICAR) }\end{array}$ & 592,41 & 694,47 & 736,74 & 665,64 & 663,89 & 653,36 \\
\hline $\begin{array}{l}\text { Indian Council of Medical } \\
\text { Research (ICMR) }\end{array}$ & 119,97 & 148,13 & 156,22 & 150,72 & 143,62 & 138,29 \\
\hline Total & 5210,28 & 5963,93 & 5872,95 & 5341,44 & 5328,91 & 5747,05 \\
\hline
\end{tabular}

Source: Official statistics of R \& D data 2017-2018 // Department of Science and Technology of India. 2017. http://dst.gov.in/research-and-development-statistics-2017-18-december-2017 (accessed: 01.02.2018).

Another important indicator of the effectiveness of India's NIS is the export of innovative products. High-tech products include goods with a high share of $\mathrm{R} \& \mathrm{D}$ costs in such areas as aviation, space, computer technology, pharmaceuticals, research instruments and electrical equipment. Exports of high-tech products from India began to grow rapidly from 2002 to 2016, as evidenced by official data from the World Bank (Figure 3).

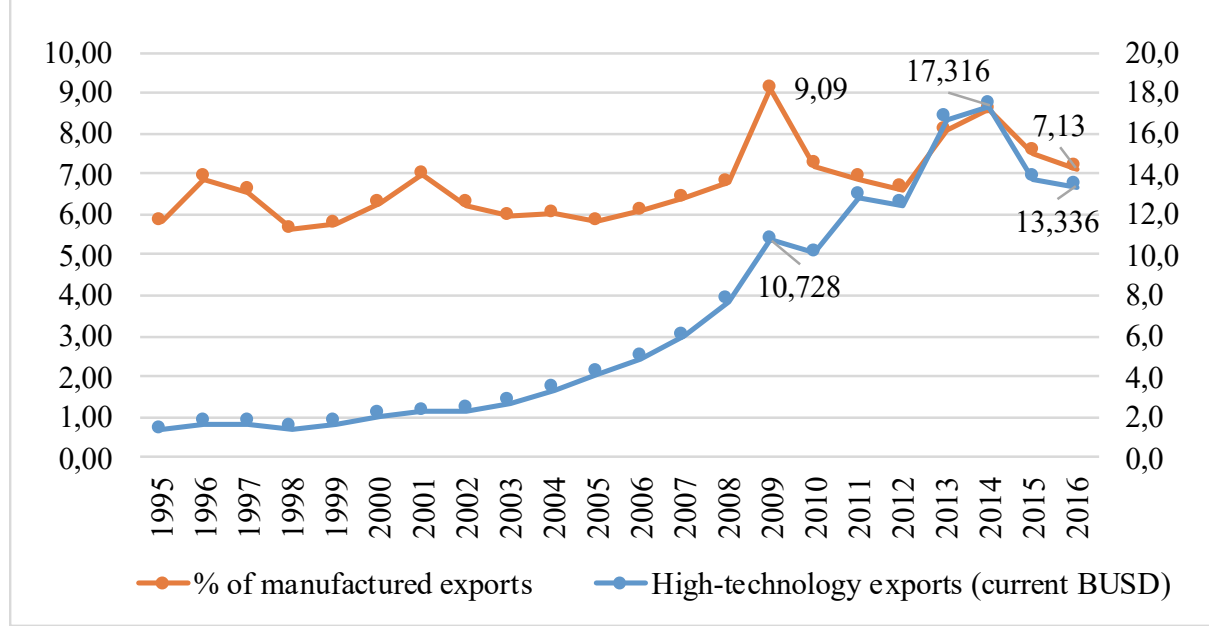

Figure 3. Exports of high-tech products in India, billion dollars, $\%$ of total manufactured goods exports, 1995-2016

Source: composed by the author on the basis of: DataBank World Development Indicators. The World Bank, 2018. http://databank.worldbank.org/data/reports.aspx?source=world-development-indicators\&Type= TABLE\&preview=on\# (accessed: 03.06.2018).

The global financial crisis has affected this indicator for India. But the country was able not only to restore her export volumes, but also to increase it many 
times. For the period from 2010 to 2014 India increased its performance by 6,5 billion dollars, reaching 17,3 billion dollars in 2014. But despite such a jump in absolute terms, the share of high-tech goods in total exports of manufactured goods after a sharp fall in 2010 could not reach the highest point of 9\%, as in 2009 . The weighted average share of high technology in India's total exports from 1995 to 2016 was $6,73 \%$, in 2016 this share was $7,13 \%$. It is noteworthy that this indicator, starting in 2014, just like the share in total exports, began to fall.

Table 3

The main investment sectors of FDI in India, million dollars, 2015-2018

\begin{tabular}{lcccc}
\hline \multicolumn{1}{c}{ Sector } & $\mathbf{2 0 1 5 - 2 0 1 6}$ & $\mathbf{2 0 1 6 - 2 0 1 7}$ & $\mathbf{2 0 1 7 - 2 0 1 8}$ & \% of total FDI \\
\hline Service sector, including R\&D & 6,889 & 8,684 & 6,709 & 18 \\
Computer technology and software & 5,904 & 3,652 & 6,153 & 8 \\
Telecommunications & 1,324 & 5,564 & 6,212 & 8 \\
Building & 113 & 105 & 540 & 7 \\
Automotive industry & 2,527 & 1,609 & 2,090 & 5 \\
Trade & 3,845 & 2,338 & 4,348 & 5 \\
Pharmaceutical industry & 754 & 857 & 1,010 & 4 \\
Chemical industry & 1,470 & 1,393 & 1,308 & 4 \\
Energy & 869 & 1,113 & 1,621 & 4 \\
\hline
\end{tabular}

Source: Fact sheet on foreign direct investment (FDI) / Department of Industrial policy and promotion, Government of India. 2018. http://dipp.nic.in/sites/default/files/FDI_FactSheet_29June2018.pdf (accessed: 29.06.2018).

Investments are noted as a separate element in the innovation system of India, which takes $8^{\text {th }}$ place in the world in terms of investments to the innovation sector. Since 1995, investment has grown by about $8 \%$ per year. India is considered as one of the most attractive countries for investing in innovation. There are main sectors that are most attractive to FDI in 2015-2018 in the Table 3.

According to the Table 3 the most attractive sector for FDI investments is the high-tech services sector. The second place is the computer technology and software sector, as well as the telecommunications sector.

Thus, we need to note that the innovative potential of India is based on the support of government agencies, which account for almost half of the country's R \& D expenses. Nevertheless, it is necessary to note the growth of investments from the private sector, which indicates the movement of the NIS of India towards maturity and qualitative growth. Regarding the export of high-tech products, here India boasts a rapid growth rate, despite slight disruptions in the trend due to economic crises. Moreover, India's NIS is considered as one of the most attractive innovative systems in terms of investment, especially in the field of computer technology and software.

\section{Conclusion}

India began a large-scale economic liberalization at the beginning of 1990s. There was significant growth in terms of GDP, exports, employment, investment, the inflow of foreign technology and investments, the ICT industry growth, the internationalization of investment in R \& D, etc. Over the years, the Indian NIS has helped to create a high level of human resources thanks to a skilled workforce. 
Thus, India has become one of the major players in the field of IT software and research services. Differences in wages and skilled human capital (including a large number of English-speaking skilled labor) appear to be the main success factors in these areas.

Otherwise it can be said that the Indian NIS also faces serious problems, such as an imbalance in income and wages, a low literacy rate and a high level of poverty, an uneven flow of foreign investment in different regions. Some of the old problems also persist, such as a lack of an innovation culture in manufactured products and weak connections between research institutions/universities and the industry, the one-way growth of the ICT sector that dominates others, and serious shortcomings in the education system.

The Indian NIS needs to solve and overcome these problems if India wants to achieve its goal to become a developed economy. However, liberalization of NIS may not be enough to realize the full potential of the Indian innovation system. This requires fundamental changes in institutions (including private and public companies) and the culture of research, as well as how they interact with each other, as well as with industry and society.

\section{References}

Aalborg University. (2018). Development, Innovation and International Political Economy Research 2018. Denmark.

Bhojani, R. (1985). Electronic policy: a package of surprise. Commerce, (150), 807-808.

Cooper, C. (1988). Supply and Demand Factors in Technology Imports. Technology Absorption in Indian Industry (pp. 117-123). New Delhi: Wiley Easter Limited.

Department of Science and Technology of India. (2017). Official statistics of $R \& D$ data 2017-2018. Retrieved from http://dst.gov.in/research-and-development-statistics-201718-december-2017 (accessed: 01.02.2018).

Eisemon, T. (1984). Insular and open strategies for enhancing scientific and technological capacities: Indian Educational expansion and its implications for African Countries. Technological Capability in the Third World (pp. 269-277). London: Macmillan.

Getty, S. (2003). BT: Call centres better in India (pp. 37-48). London: Metro.

Goldar, B., \& Ranganathan, V. (1998). Economic reforms and R \& D expenditure of industrial firms in India. Indian Economic Journal, 461(2), 60-75.

Government of India. (2017). Research and development statistics at a glance 2017-2018. Department of Science and Technology (pp. 3-5). New Delhi, India.

Government of India. (2018). Fact sheet on foreign direct investment. Department of Industrial policy and promotion. Retrieved from http:/dipp.nic.in/sites/default/files/FDI_FactSheet 29June2018.pdf (accessed: 29.06.2018).

Government of India. (2018). Twelfth Five Year Plan (2012-2017): Faster, More Inclusive and Sustainable Growth. Planning Commission. Retrieved from http://www.planningcommission. nic.in/plans/planrel/fiveyr/12th/pdf/12fyp_voll.pdf (accessed: 01.03.2018).

Index Mundi. (2014). Charges for the use of intellectual property, receipts. India - Royalty and license fees. Retrieved from http://www.indexmundi.com/facts/india/royalty-andlicense-fees (accessed: 18.09.2018).

Khandelwal, K. (1981). The electronics industry: aspects and prospects. Commerce, (142), $10-13$.

Kumar, N., \& Agarwal, A. (2000). Liberalisation, outward orientation and in-house R \& D activity of multinational and local firms: a quantitative exploration of Indian manufacturing. Research Policy, 34(4), 441-460. 
Mascarenhas, R. (1982). Technology Transfer and Development: India's Hindustan Machine Tools Company (pp. 3-15). Colorado: Westview Press.

National Innovation Council. (2018). Towards a Decade of Innovation 2010-2020. Retrieved from http://innovationcouncilarchive.nic.in/index.php?option=com_content\&view= category\&layout=blog\&id=25\&Itemid $=28$ (accessed: 15.02 .2018$)$.

The World Bank. (2018). DataBank World Development Indicators. Retrieved from http://databank. worldbank.org/data/reports.aspx?source=world-development-indicators\&Type=TABLE\& preview $=$ on\# (accessed: 03.06.2018).

Webeconomy.ru. (2017). 12-year plan of India. Retrieved from http://www.webeconomy.ru/ index.php?page $=$ cat\&newsid=1723\&type $=$ news (accessed: 14.02.2018).

\title{
Article history:
}

Received: 15 November 2019

Revised: 25 November 2019

Accepted: 10 December 2019

\section{For citation:}

Bokachev, I.N. (2019). National innovation system of India: genesis and key performance indicators. RUDN Journal of Economics, 27(4), 774-785. http://dx.doi.org/10.22363/23132329-2019-27-4-774-785

\section{Bio note:}

Ivan N. Bokachev, senior Real Estate manager, PAO "Vympel-Kommunikatsii". E-mail: ibokachev@gmail.com

Научная статья

\section{Национальная инновационная система Индии: процесс становления и основные показатели эффективности}

\author{
И.Н. Бокачев \\ ПАО «Вымпелком-Коммуникации» \\ Российская Федераџия, 127083, Москва, ул. 8 Марта, д. 10, стр. 14
}

В статье рассматривается процесс формирования национальной инновационной системы Индии, который проходит через фазы протекционизма, либерализма и дуальности. Особое внимание уделяется особенностям национальной инновационной системы Индии на базе показателей эффективности, таких как валовые внутренние расходы на НИОКР, экспорт высокотехнологичной продукции, а также прямые иностранные инвестиции в сфере высоких технологий. В работе отмечается, что Индия является одной из самых привлекательных стран для инвестирования в инновационную сферу. Автор выделяет также и негативные стороны развития НИС Индии, такие как дисбаланс в доходах и заработных платах, низкий уровень грамотности и высокий уровень нищеты, неравномерный приток иностранных инвестиций в разные регионы, отсутствие культуры инноваций в производимых продуктах и слабые связи между научно-исследовательскими учреждениями и отраслью, а также односторонний рост сектора ИКТ. Тем не менее в статье особенно отмечается, что Индия после начала процесса экономической либера- 
лизации экономически выросла с точки зрения уровня ВВП, экспорта, занятости, инвестиций, притока иностранных технологий и инвестиций, индустрии ИКТ, а также интернационализации инвестиций в НИОКР.

Ключевые слова: национальная инновационная система, Индия, экономическое развития, НИОКР, инновации, высокие технологии, инновационные потенциал

\section{История статьи:}

Дата поступления в редакцию: 15 ноября 2019

Дата проверки: 25 ноября 2019

Дата принятия к печати: 10 декабря 2019

\section{Для цитирования:}

Bokachev I.N. National innovation system of India: genesis and key performance indicators (Национальная инновационная система Индии: процесс становления и основные показатели эффективности) // Вестник Российского университета дружбы народов. Серия: Экономика. 2019. Т. 27. № 4. С. 774-785. http://dx.doi.org/10.22363/23132329-2019-27-4-774-785

\section{Сведения об авторе:}

Бокачев Иван Николаевич, ведущий менеджер по управлению эффективностью ПАО «Вымпелком-Коммуникации». E-mail: ibokachev@gmail.com 